\title{
THE PLATONIC INFLUENCE ON EARLY CHRISTIAN ANTHROPOLOGY: ITS IMPLICATION ON THE THEOLOGY OF THE RESURRECTION OF THE DEAD
}

\author{
Onyeukaziri Justin Nnaemeka \\ Fu Jen Catholic University, Taiwan
}

\begin{abstract}
The objective of this work is to investigate the philosophical anthropology that underpins the anthropology of the Early Christians. It is curious to know why Christian anthropology is intellectually and practically inclined towards the philosophical anthropology of the Platonic tradition rather than the theological-philosophical tradition of the biblical Hebrew people in the Old Testament. Today the emphasis on Christian anthropology is that the human person is an integration of body and soul. Contrary to this position, the writer maintains that the Christian anthropology, especially during the period of the early Christians (here understood as the period within the first five centuries C.E.), fundamentally conceives the human person as a composite of soul and body, which is a conscious employment of Platonic anthropology. This article observes that, as regards the doctrine of the resurrection of the dead, there is a dichotomy between theological coherency and the actual Christian practice on the Christian conception of the human person. Hence, this work argues that the Platonic influence on the philosophical anthropology of the Early Christian was a deliberate act to give a more rational foundation to the theological problematic on the resurrection of the dead and on the resurrected body. It explains why Aquinas's theological cum philosophical thinking, though overwhelmingly an Aristotelian ground, could not "Aristotelize" his philosophical anthropology.
\end{abstract}

Keywords: Christian anthropology, body, soul, death, resurrection, Platonism, theology

\section{INTRODUCTION}

The objective of this work is to investigate the philosophical anthropology that underpins the anthropology of the Early Christians. Here the period of the Early Christians is delimited to be the period within the first five centuries C.E. It is curious 
to know why Christian anthropology is intellectually and practically inclined towards the philosophical anthropology of the Platonic tradition rather than the theologica-philosophical tradition of the biblical Hebrew people in the Old Testament. Christian theologians may differ in their understanding and interpretation of the doctrine of the resurrection of Jesus. However, there is a consensus in maintaining that the doctrine of the resurrection of Jesus is the foundational doctrine of which every Christian doctrine and the entire Christian faith stands. In one of the Letters of the New Testament, attributed to St Paul as the human author (I Corinthians 15), St. Paul argues that the resurrection of the departed Christian is unshakably based on the resurrection of Jesus.

The question of the Bodily resurrection of Jesus, though unequivocally affirmed by the Catholic Church, remains a theological problem. Notwithstanding St. Paul's effort to theologically make sense of it in I Corinthians 15, the nature of the resurrection of departed Christians has added to the lurking theological problem rather than reduced it. St. Paul's theology of the resurrection of the dead is not only determined by his faith in the resurrection of Jesus but is critically conditioned by his philosophical anthropology. Hence, this work argues that the Platonic influence on the philosophical anthropology of the Early Christian was a deliberate act to give a more rational foundation to the theological problematic on the resurrection of the dead and on the resurrected body. It explains why Aquinas's theological cum philosophical thinking, although overwhelmingly an Aristotelian ground, could not "Aristotelize" his philosophical anthropology. Aquinas's philosophical anthropology remains fundamentally Platonic in nature. This work will keep the spirit of early Christian thinking and Scholastic philosophy, whereby there is always a philosophical and theological interplay in the effort to grasp the truth. Hence, to execute this work, the following steps will be followed: 1 . A brief exposé on philosophical anthropology. 2 . A brief navigation of biblical anthropology. 3. An exposition of Platonic anthropology. 4. Early Christian anthropology and Its Platonic influence. 5. The implication on the Resurrection of the dead and on the Resurrected body. Finally, there will be a Conclusion.

\section{A BRIEF EXPOSÉ ON PHILOSOPHICAL ANTHROPOLOGY}

Philosophy as an epistemic inquiry claims to possess the instrumentum laboris to grasp a wholistic rational knowledge of the human person by investigating critically the quiddity or whatness of the human person. This claim is based on its epistemic method to grasp the fundamental grounds of things, the human person included. Since the time of Plato, the nature of the human person, including what can be known and how the human person knows, has been the central focus of Western philosophy.

The primary objective of philosophical anthropology is to have a comprehensive understanding of the human person by considering all the aspects of the human person both as a metaphysical whatness and as an ontological thisness. Thus, it focuses on developing through the aids of reason and human experience a comprehensive understanding of the essence, the nature, the concrete condition of an individual person as an agent or subject, and the telos of the human person. Simply put, the principal 
question in philosophical anthropology is: What is the human person? Within the framework of this paper, the fundamental question is: What is the human person for the early Christians? Or put differently, how did the early Christians conceive the human person?

\section{A BRIEF NAVIGATION OF BIBLICAL ANTHROPOLOGY}

The starting point for any fruitful discourse on biblical anthropology always begins from the first book of the Judeo-Christian Sacred text, the first book of the Pentateuch, the book of Genesis. The first three chapters of the book of Genesis give two, materially different but essentially the same, accounts of the creation of the universe. Both creation accounts make the following claims: In the First account, the universe is created, the universe is created in time, God created the universe, God created the universe ex nihilo, the earth is a created order out of chaos, God made man in His own image and likeness and gave man dominion over other creatures. In the Second account, God made man from matter (the dust of the earth), but man becomes a nephesh "living being" when God breathed into it the nishmat chayyim," "breath of life." Man is made out of necessity to till the ground; God made man with the freedom to choose to obey or disobey His command, the woman was made out of man as a suitable partner for the man. Man and woman were both innocent and shameless until they sinned. There is an anti-God being that causes man and woman to disobey God's command. Man and woman freely choose to disobey God's command. Sin brings shame, pain, suffering, and death. ${ }^{2}$

The Hebrew term, nephesh, has suffered diverse translations, but what is definite is that it is neither the Platonic, the Aristotelian, nor any other Hellenistic notion of the soul. Etymologically, it has been traced to the Akkadian napasu, which means "expand," and napistu, which means "throat" or "neck," and the Arabic connotation of it means "breath." The usage of nephesh has evolved throughout the Old Testament. Since this work does not aim at an exegesis of the term nephesh, it will be simple to maintain here that the composite understanding of the human person as consisting of two substances, body and soul, is basically not the anthropology of the Old Testament. Thus, when Abraham, Isaac, and Jacob, for instance, died, the Hebrew people were not expecting the immortal existence of their souls. Though they do not have the notion of a soul, they nevertheless believe in the afterlife. They believed that their ancestors were in the realm of the dead, which is commonly referred to as sheol. ${ }^{3}$ In sheol, the living being continues to live as an ancestor. Hence, for them, mavet, "death," is not conceived as the separation of the soul from the body since there is no notion of composite anthropology, though there is a doctrine of afterlife. ${ }^{4}$ The belief in the resurrection of the dead/body evolved during the period of the Hellenization of the Hebrew people. We find references to this belief in the deuterocanonical books and apocryphal books of the Old Testament. ${ }^{5}$ Hence, there becomes an evolution in the eschatology that maintains that death is not the final end of the human being and the strong belief in the reward of the righteous and the punishment of the unrighteous after death. ${ }^{6}$ 


\section{AN EXPOSITION OF PLATONIC ANTHROPOLOGY}

During the period of the early Christians, say, from the period of the apostles to the fifth century, the intellectual climate of the time was deluged with diverse philosophical traditions and systems. This period is what is usually called the Hellenistic period. The philosophical traditions of the Hellenistic period were not only philosophies for the sake of philosophical knowledge; they were also different forms of spiritual ways. Among these philosophical traditions includes Neoplatonism, Stoicism, Epicureanism, and Gnosticism. As a spiritual way, Christianity was a latecomer that had to compete with more established intellectual systems of Neoplatonism, Stoicism, Epicureanism, and its contemporary, Gnosticism/GnosticManicheanism. By combating any of these rival philosophical cum spiritual traditions, the early Christians consumed the intellectual materials of these traditions by using their thoughts as an argumentative arsenal against another. By doing so, in different shades and manners, the theology and spirituality of the early Christians were in no little way influenced by these philosophical cum spiritual traditions.

Considering the constant rivalry between the Neoplatonists, as demonstrated in the works of Plotinus and Porphyry, against the Stoics, Epicureans, and especially the Gnostics, which is a contemporary rival tradition with Christianity, the Early Christians expectedly rooted more for Neoplatonism. Speaking specifically, the philosophical anthropology of the Platonic tradition resonates more with the Early Christians than any of the other traditions mentioned above. Hence, below is a brief exposition of the philosophical anthropology of the Platonic tradition. Emphasis is on the thought of Plato and Plotinus, the founder and the apostles of the Platonic tradition, respectively.

The dialogue of Plato [428/427-348/347 B.C.E] Phaedo ${ }^{7}$ more comprehensively exposes Plato's philosophical anthropology. It gives a dramatic narration of the last hours and death of the philosopher and teacher of Athens, Socrates [399-470 B.C.E]. It is mainly a conversation between Echecrates and Phaedo, after which the dialogue is named.

The discussion of the death of Socrates in Phaedo raises the question of death as the inevitable fate of the human person. However, the question of more philosophical interest presented by the interlocutors in Phaedo is the nature of the human soul and the reality of the immortality of the soul. Socrates-Plato in the Phaedo (64a), maintains that philosophy is the means not only to conquer death but, more importantly, the means to prepare the soul for immortality. Since death is conceived as the freedom and separation of the soul from the body, Socrates in the Phaedo $(67 \mathrm{~d})$, maintains that the "release and separation of the soul from the body is the preoccupation of the philosophers." Thus, the Platonic anthropology which posits the human being as consisting of two distinct entities, $\psi v \vee \chi \eta$ (the soul), which is spiritual and incorruptible, and $\sigma \omega \mu \alpha$ (the body), which is physical and corruptible. The soul is considered the ruler and master of the body, for it is the soul that detects the activities of the body. ${ }^{8}$ Therefore, the soul is at its best when it disassociates itself from the troubles of the senses, either as pain or as pleasure (Phaedo, 65c). Hence, in Phaedo (65a) he contends, "the philosopher more than other men frees the soul from 
association with the body as much as possible." By despising the body and every activity that gratifies the body, the body has been adjudged as not the essential component of the human being. Thus, the body is a burden to the soul in the activities of grasping the truth. In Phaedo, the argument of learning as recollection was employed, and the argument based on the harmony of distinct things was refuted to demonstrate the immortality of the soul. ${ }^{9}$

Most of the early Christian thinkers encountered Plato's philosophy indirectly by encountering Plotinus [c. 204/5-270 C.E.], arguably the most faithful "apostles" of Plato. As a Platonist, Plotinus's worldview is an idealist. He maintains the key trends of Plato's cosmology and cosmogony. ${ }^{10}$ Plotinus ${ }^{11}$ in Against the Gnostics (Book II, $9(1), 10)$ believes in a world that is structurally ordered, with three hypostases: The One, the Intellect, and the Soul. The One is the First "in the sense that it is simplest, and the self-Sufficient because it is not composed of a number of parts." From the one comes the Divine Intellect, which contains the Forms of all things. After the Divine Intellect comes the Soul, and then the bodies and all other lower realities of purely corporal nature. According to Plotinus in Against the Gnostics (Book II, 9(1), 5-10), the One is the generative force of all things; thus, it is the transcendental Absolute Being, Good, Beauty and Truth. Thus, the One is beyond the complete grasp of every human language. ${ }^{12}$ The One is eternally transcendent from the world but yet immanent in the world. In the same way, other levels of being in the Plotinus's universe are not completely apart from one another. Hence, though the Divine Intellect, the Soul, and body are distinct beings, the body is in the soul, the soul is in the Intellect, and the Intellect is in the One. While the One is the Absolute Good, Plotinus conceives matter, the sense-world, as the principle of evil (in the moral sense). Plotinus, in $O n$ Providence (1) (Book 3(2),15-25), employs a rational formative principle which he calls Logos, ${ }^{13}$ that flows from the Intellect, to explain the becoming and order of all things by providence.

Plotinus in the Ennead (Book 1.1, 5) initiates his discourse on the human person by inquiring about the possible source of human passions and desires. By this inquiry, he maintains that the human person (the living being) is either: the soul, the soul using a body, or a thing composed of both the soul and the soul using a body. He (Book 1.1, $3,5-15)$ agrees with Plato on the composition of the human person as made up of soul and body and that the soul uses the body as a tool. Hence, he contends that the soul does not have to receive affections from the body. Moreover, he holds that the soul is not composite, for the soul and soulness (the essential soul) are one and the same. The soul is a substantial being, thus unmixed. He (Book 1.1,7, 15-20) maintains that the soul alone, not with the body, receives its lordship over the living being from the ability to grasp the forms of things. From these forms come 'reasonings, and opinions and acts of intuitive intelligence; and this precisely is where "we" are.' The "we" is the intellectual parts of the soul, which according to Plotinus, is actually the human person. This idea of "the intellectual parts of the soul" should be considered as an Aristotelian influence. This influence must have informed Plotinus's "partition" of the soul. Even though Aristotle in On the Soul (411b1-30) seems to conceive the soul as a homogeneous whole that constitutes inseparable parts. Plotinus further distinguishes 
three parts or three kinds/faculties of the soul, intellective, affective, and vegetative souls. He distinguishes the soul into the higher part and the lower part. The higher part ("we") is the rational part, which is the human person, while the lower part ("ours") is the appetitive part - "the lion-like" and "the various beast." 14 This is no doubt an Aristotlenized Platonic anthropology by Plotinus. Although, according to Ennead (Book 1.1,7, 15-20), for Plotinus, the human person is the intellectual part of the soul, however, he has no objection to calling the combination of the "we" and the "ours" the "living being." Hence, he uses "we" in two senses, either as including "the beast" or referring to that which even in our present life transcends it. The higher part of the soul, the true human person, he (Book 1.1,10,1-5;5-10;10-15) maintains belongs to the sphere of the intellect and has its "seat actually in the separate soul, separate and separable even while it is still here below."

\section{EARLY CHRISTIAN ANTHROPOLOGY AND ITS PLATONIC INFLUENCE}

During the period of the early Christians, the general understanding of the human person across the different intellectual cum spiritual systems was basically: the human person possesses a physical substance, body, and a spiritual substance, soul. ${ }^{15}$ The philosophical cum theological problem is how to rationally explain the relationship between the two substances that constitute the human person. The explications range from clear dualism in the Platonic tradition to clear monism in the Epicurean tradition. The Aristotelian and the Stoic traditions oscillate between the dualism of the Platonic tradition and the monism of the Epicurean tradition. As could be seen in the works of Plato, especially in Phaedo, even at the time of Plato, different explanations were posited as attempts to explain the relationship between the body and the soul. Hence, during the period of the early Christians, the prevailing anthropological postulations are the harmony of the soul and body, the body as the house or prison of the soul, the soul as the pilot of the ship-the body, the soul as the form of the body (matter), composite of soul and body, and the soul and the body as a unity or integral. While the harmony, house/prison/pilot, and hylomorphic metaphors, were the leading postulations during the period of Plato and Aristotle, the metaphor of mixture of soul and body was the philosophical, anthropological paradigm during the nascent period of Christianity. Margaret R. Miles $(1979,2)$ describes it thus: "The idea of the composite was deeply troubling both to classical (Stoic and Neoplatonic) and to dualist (Gnostic-Manichaean) thought. It described an experience of contamination of the higher by the lower elements".

Today the unity or integration paradigm has been maintained as the Christian anthropology since the period of the early Christians. ${ }^{16}$ The writer contends that this position, especially during the period of the early Christians, is held more for the purpose of maintaining theological coherency on the Christian beliefs in the incarnation and the bodily resurrection of Jesus. However, from the perspective of Christian life and practice, the common attitude of the early Christians was basically a dualistic anthropology that sees the body as that which inhibits the soul. Hence, the Early Christians conceive death as the separation of the soul from the body. ${ }^{17}$ This 
conception, which remains the same in today's Christianity, is fundamentally the Platonic conception of death. It presupposes that the human person is a composite of body and soul. ${ }^{18}$ This conception of the human person as a composite of body and soul and the conception of death as the separation of the soul from the body is not fundamentally a Jewish's anthropology and conception of death. ${ }^{19}$ Karl Rahner (1961, 16) asserts: "The description of death as the separation of body and soul is, however, used so much as a matter of course from the earliest Fathers down to the catechism of Cardinal Gasparri, that from the theological point of view we must consider it as the classical theological description of death." Since this anthropology and its consequent conception of death is strange to the Hebrew people of the Old Testament and thus not fundamentally Jewish, the question is, how did it become that of Christians, holding the fact that Jesus and the apostles, including St. Paul, were all Jews?

Now considering the question of the fate of those who died in Christ in $I$ Corinthians 15, though St. Paul based his argument for the resurrection of the body on the resurrection of Jesus Christ, the theological notion on the resurrection of the body has been a common idea shared by certain schools of thoughts among the Jews before and during the time of St Paul. A clear case in point documented in the New Testament was the Pharisees (Acts 23:6-9), who, contrary to the Sadducees, believe in the resurrection of the dead. This doctrine on the resurrection of the dead and specifically on body resurrection seems strange to the Greco-Roman worldview. An instance of this is the reactions of the Athenians and the Roman Judge Festus, as documented in the Acts of the Apostles. St. Paul in the city of Athens, after debating with some Jews and some god-fearing fellows, also contended with some Epicurean and Stoic philosophers in debate among other issues, on the subject of Jesus and Resurrection. We are told that the subject of the Resurrection of Jesus was funny to the philosophers listening to Paul. The philosophers (See Acts 17:16-34) called the subject of Resurrection a "new doctrine," and out of intellectual curiosity, they beseeched Paul to expound the "new doctrine" to them. Another incident was during Paul's missionary journey in Rome. The Apostle Paul's new teaching and preaching caused an uproar among the Jews in Rome, which brought him before the court of the Roman governor Felix for bringing destabilization in the city as alleged by the high priest and elders of the Jews. Paul (Acts 24:1-21), before the Governor Felix, pleaded not guilty; he admitted that he had done nothing but preach and teach the subject of the Resurrection of the dead to both the upright and the wicked alike.

After Felix was succeeded by Porcius Festus as the governor, Paul, still in custody, was brought before King Agrippa, and before both of them, Paul made his defense, still claiming that he had done nothing wrong except for believing in the resurrection of the dead. Paul on trying to expound the credibility of the subject of the Resurrection of the dead, though maintains that it is the hope promised by God to his ancestors, however, he had to appeal to his personal encounter with Jesus Christ and his conversion to Christianity as the solid ground of his belief in the resurrection of the dead. This appeal to personal experience is noteworthy given that it was also a group of Jews from Asia that accused him before the Roman authorities. This means that what Paul claims to be "the hope promised by God to his ancestors" is not a generally 
accepted hope or belief among the Jews at the time. Festus (Acts 26:1-23), unable to sustain the persuasive argumentation of Paul on the subject of the resurrection of the dead based on his personal encounter with Jesus, declared Paul as mad and out of his mind. Therefore, it should be said that although the belief in the resurrection of the dead has its antecedent in some sects of Judaism, it was the resurrection experience of Jesus Christ that brought a substantial evolution in the Christian conception of the human person from that of the Hellenistic philosophers. To make sense of the tension between the Christian doctrine of the resurrection of the dead and Platonic conception of the human person posits an enormous intellectual challenge to many thinkers of the early Church. The scholastic theologians and philosophers appealed to Aristotle's metaphysics of the soul and body, but not on his philosophical anthropology per se, as a way of dealing with the problem of the resurrection of the dead, that is to say, the resurrection of the whole person as claimed by Paul and believed by the Church.

The question of the fate of the dead and the nature of which the dead will exist are principal problematics of religion as an epistemic inquiry. The early Christians battled with these problematics. Christians, by revelation, believe not only in the resurrection of the dead but also in the bodily resurrection of the dead. However, the difficult task before the early Christians was how to make sense of it and rationally defend it before opponents of this belief. The doctrine of the resurrection of the body by the early Christian, beginning with St. Paul has been based on two theological grounds: the resurrection of Jesus Christ and the omnipotence of God. The belief in the incarnation of Jesus also conditions the Church's philosophical anthropology. The doctrine of the incarnation, in a fundamental way, makes a positive notion of the human body necessary. It becomes the ground for the positive theology of the human body/flesh, scantly present in few writings of the early Christians but strongly emphasized in contemporary theology of the Church. John Paul II's (2006) Theology of the Body is a case in point. The logic is simple; if God takes flesh in Jesus and lives in human form with body and soul, then it would be scandalous to demonize or cast aspersions to the human body/flesh. What it means is that any philosophical anthropology that opposes the integral nature of the human person and affirms the goodness of the human body and soul becomes unacceptable in the theological formulation of the Christian conception of the human person.

The early Christians were vociferously attacked mainly by the Gnostics on the question of the resurrection of the body, and they had to justify their belief as revealed in the Scriptures. The following Fathers of the Church are examples of those who had to combat the attacks on the resurrection of the body: Tatian, in his "Oration Against the Greeks" Ch. 6, Athenagoras, in his "The Resurrection of the Dead," Ch. 12, Minucius Felix, in his "Letter to Octavius," Ch. 34, Tertullian, in his "On the Resurrection of the Flesh," Ch. 14, St. Clement of Alexandria, in his "Adumbrations in 1 Peter 1:3, Origen, in his "Against Celsus," Bk. 5, Ch. 22, St. Methodius, in his "On the Resurrection," Ch. 12, St. Ambrose in his "On the Death of his brother Satyrus," Bk. 2: 87, St. Augustine, in his "The City of God," Bk. 22, Ch. 20, and in the "Second Letter of St. Clement of Rome to the Corinthians," Ch. 9:1. Below, the writer quotes the position of St. Justin Martyr in his "The First Apology, Ch. 18," mainly because he directly makes reference to the Platonists in his argument for the 
resurrection of the body: "Such favor as you grant to these \{Pythagoreans, Platonists, et al.\} grant also to us, who not less but more firmly than they believe in God; since we expect to receive again our own bodies, though they are dead and cast into the earth, for we maintain that with God nothing is impossible."20

Like Justin Martyr, the argument for the resurrection of the body in the works of the Early Christians is a theological argument based on the Omnipotence of God. However, the question is, why appeal to the Omnipotence of God, when the Pythagoreans and Platonists (Timaeus 42a-d) also believe in resurrection/transmigration of the dead into different body forms, including the human body, as depending on the life of a person in this present world? The Pythagoreans and Platonists (influenced by the Pythagoreans), based on certain mythology, believe in the immortality of the soul, which transmigrates from one form of a living thing to another. Justin Martyr is arguing that if they (Pythagoreans and Platonists) with faith and knowledge believe in the possibility of the transmigration of the soul of a human being after death, how then can it not be possible for them to believe that God, who is Omnipotent, can clothe the immortal soul of a dead Christian with a new body.

According to the most prominent of the Christian Platonists during the period of the early Christians, Augustine, in The City of God, expounding the notion of "regeneration" used in Matthew 19: 28 about the last judgment, he (The City of God, Book XX, 5) maintains that it implies the resurrection of the dead, "for our flesh shall be regenerated by incorruption, as our soul is regenerated by faith." In The City of God (Book XX, 6), he considers the resurrection of the body as "the second resurrection," thereby distinguishing it from "the resurrection of the soul or spiritual resurrection," for the soul, according to him, dies due to sin. In The City of God (Book XX, 6), he contends that all the righteous and the wicked would share in the second resurrection (the resurrection of the body). However, only the eternally blessed (those who hear, respond and keep the voice of Christ) experience the first resurrection (the resurrection of the soul). The latter he calls "the resurrection of mercy," the former he calls "the resurrection of judgment." By this, Augustine implies that the resurrection of the body is for the last judgment, but only those who repent of their sin and are justified by faith in Christ experience the resurrection of the soul in the present life. This clear and distinct separation of the body and the soul and their respective separate resurrections shows a strong platonic anthropological influence in Augustine's theology of the last judgment and resurrection. This view of Augustine was not a popular one at the time. He (The City of God, Book XX, 10) had to defend his view against those who do not believe in the resurrection of the soul.

\section{THE IMPLICATION ON THE RESURRECTION OF THE DEAD/BODY}

From the ongoing discussion, the writer's position is that fundamentally the anthropology of the early Christians, which essentially speaking remains the same today, is in line with that of the Platonic tradition, which conceives the human person as a composite of body and soul. And by this anthropology, death is conceived ${ }^{21}$ as separation of the soul from the body. This is not to deny the fact that sparingly there 
are present assertions in the writings of few of the Church fathers on the unitary or integral conception of the human person. The writer's position, contrary to the view that exclusively maintains the integral conception, is that from the standpoint of practical Christian life, the unitary conception of the human person in the early Church is the exception rather than the rule. This exception is a result of the need to maintain a necessary theological coherency, which is the theological affirmation of the revealed truth of the resurrection of the body or flesh, as the case may be. ${ }^{22}$ If there is the resurrection of the body, then the human person must be an integral of body and soul in order for the dead to rise integrally as soul and body.

It was a huge challenge for the early Christians to defend this position rationally, and the problem was compounded considering the assertion of the Apostle Paul in $I$ Corinthians 15:50 that "flesh and blood cannot inherit the kingdom of God, nor does the perishable inherit the imperishable." Hence, while this position, that is, a human being as an integral of body and soul, is theologically maintained, in actual Christian practice, the anthropology at work is that of the composite of two distinct substances, body and soul. This is one of the many conflicts between theory and praxis or theology and spirituality, which is inherent in the nature of religion. Thus, the doctrines and dogmatic teachings on mysteries in different religions are made necessary. It is no surprise that this theological affirmation of the resurrection of flesh/body is maintained as a dogma of faith in the "Apostolic Creed." This is not only because of its implication in the dogmatic teaching on the incarnation and bodily resurrection of Jesus but, more importantly, as an exigent circumstance to combat the Gnostic-Manichaean heretic attack that contends that the human body/flesh is evil. The early church had to defend the goodness of the human body, for the Second Person of the Trinity, incarnated in the flesh and resurrected in body, are teachings essential to the Christian faith.

On the other hand, the anthropology of the human person as a composite of distinct substances, body, and soul is densely populated in the writings of the Early Christians. This is because notwithstanding the dogmatic belief on the resurrection of the body, in reality, the Christian spirituality, morality, and liturgy, are rather formed by the anthropology of the composite of distinct substances, body, and soul. The wave of ascetic practices and willingness to accept martyrdom during the Early Church is the most fortified argument for the Platonic anthropology of a composite of body and soul. The Desert Fathers and later Christians who took to monastic practices during the period of the Early Church were bent on subduing the body in order to free the soul to be united with God. And the martyrs were willing to give up their body which they knew was perishable because they knew their true self, their soul, which will live forever, is imperishable. In the liturgy of the Church, since the period of the early Church until date, prayers are offered for the souls of the faithful departed, and God, the Father of all mercy, is asked to accept the souls of the faithful departed Christians. On the prevalent of the conception of the human being composed of distinct substances soul and body during the early period of Christianity, B. P. Vysheslavtsev $(2002,178)$, maintains: 'It plays an enormous role in the Christian consciousness of the Middle Ages, and for the majority of Christians it is the fulcrum of their belief in immortality. However, this theory of "disincarnated" immortality is closest to Orphism and Platonism, and therefore it is not characteristically Judaic and Christian'. In other 
words, Vysheslavtsev is arguing that even though the notion of the person in the Christians' consciousness informs their earthly life and spirituality, it is not consistent with the theological construction of the Christians' early church. The writer is arguing that this disparity between the more Platonic notion of the soul and body in the Christian consciousness and the integral theological notion of the human person still remains the same today.

The question then is: is the doctrine of the resurrection of the body necessary? Put differently, why did the early Christians consider the doctrine of the resurrection of the body necessary, that they had to write a lot of treatises to defend it? Claudia Setzer $(2009,1-12)$ suggests it is necessary "because of its utility as a symbol that aids and maintains the construction of community. It helps forge an identity in facing the powerful Greco-Roman culture beyond its borders and shores up group membership within the group." He (2009, 1-12) further maintains that it is necessary for, "It carries with it a set of essential ideas about God, the world, and humanity." Considering the fact that in the lived experience of the early Christians and of Christians today, there are no pronounced actions that demonstrate the resurrection and continuous existence of the human body after death, unlike in the practices of the ancient Egyptians and the Greco-Roman Egyptians during the period of the early Christians. ${ }^{23}$ The writer thinks that the doctrine of the resurrection of the body seems to be important only for theological coherency. Because any position that questions the possibility of the resurrection of the body not only questions the bodily resurrection of Jesus but, more so, questions the omnipotence and providence of God. Hence, the doctrine of the resurrection of the body must be theologically defended.

However, should it be philosophically defended? Moreover, can it be philosophically defended? Many Church fathers think it should be theologically defended, and they indeed theologically defended it. But, Scholastics, for example, Thomas Aquinas and Duns Scotus, not only think it should be philosophically defended but that it can be philosophically defended. They both indeed make a philosophical defense for the resurrection of the body. Based on the Aristotelian entelechy principle, for example, Aquinas, in his Summa Theologica (Part 1, Ques. 76, Art. 1), argued for the resurrection of the body. In Summa Contra Gentiles, (Chapter LXXIX, 1), Thomas Aquinas agrees with Aristotle that the intellectual soul is the form of the body, and hence, argues that: "It is against the nature of the soul to be without a body, but nothing that is against nature can be lasting. Therefore the soul will not be forever without the body. Thus the immortality of the soul seems to require the resurrection of the body." The problem with Aquinas's effort for a philosophical defense of the resurrection of the body, aside from being laden with theological or Scriptural presuppositions, is that he seems to be at pain to reconcile his version of the entelechy principle with the composite anthropology which in his demonstration appears the de facto Christian anthropology, which is basically Platonic. This created inconsistencies in his discourse on death and on the relationship between the soul and the body. For instance, in Summa Theologica (Part 1, Ques. 77, Art. 8), he maintains a composite of the human being and death as a destruction of the body. Though it appears philosophically convenient to employ the entelechy principle of Aristotle as a 
ground to argue for the necessity of the immortal soul to have a body after death, however, it is not coherent with the general philosophical anthropology of Aristotle. Aristotle's conception of the soul is radically different from the Christian conception of the soul. A fundamental difference is that, in On the Soul, Aristotle (403a10; 413a110), though he maintains that the separate existence of the soul is impossible, he does not believe in the immortality of the soul. In his works on Natural Science, he (Physics, 203a5-10) argues that "everything is either a principle or derived from a principle... a principle, is both uncreatable and indestructible. For there must be a point at which what has come to be, reaches its end, and also a termination of all passing away". The soul is derived from a principle, for Christians believe the soul is created by God, which is the Principle. If whatever comes to existence (created) cannot be eternal and imperishable, that is to say, cannot be immortal, and since the soul comes to existence, following Aristotle's argument, it means that the soul is perishable and mortal. However, on the contrary, Christians believe that the soul, though created by God, is immortal. Also, in On the Heavens, if one accepts Aristotle's (286a18; 286a32-33) assertion that: "nothing unnatural is eternal" and "it is unreasonable that a movable body should be eternal if its movement cannot be naturally eternal," as Duns Scotus concedes, one has to conclude that for Aristotle the soul is neither eternal nor immortal. According to Opus Oxoniense in Philosophical Writings (134-162), Duns Scotus (iv, dist. XLIII, q. II) contends, "the separation of the soul from the body is unnatural because it is contrary to the natural inclination of the soul. For according to the philosopher [Aristotle], the soul has a natural inclination to perfect the body." This is not to argue that Duns Scotus holds that the soul is not immortal, but it is to sustain the argument that a general look at Aristotle's philosophy shows that Aristotle does not support the belief that the soul is immortal or eternal.

Secondly, Aristotle does not consider the whole soul as the form of the human body, but only the rational part of the soul, otherwise called the intellective soul. In fact, for Aristotle, the whole soul is not really subsistent per se; it is only the intellective soul that could be said to be subsistent since it could act separately from the body. Every other part of the soul, for Aristotle, needs the body in order to act. But the Christian conception of the soul is not a partitioned substance but a unitary subsisting substance distinct from the body. Duns Scotus agrees with Aristotle that it is the intellective soul that is the specific form of man, not the entire soul. Moreover, he claimed that this could be known and demonstrated by natural reason. In reference to Aristotle, in Opus Oxoniense (iv, dist. XLIII, q. II), Duns Scotus contends, "if he grants that the intellective soul is the form of man, as is evident from the proof of the proceeding proposition, he does not admit that it exists in separation from matter, once the whole no longer exists." Thus, using a partitioned notion of the soul in Aristotle to explain the Christian notion of the soul, which is a unity, raises more philosophical questions than answers on the nature of the Christian notion of the soul. Hence, it would raise more questions and would not clarify the attempt to understand Christian philosophical anthropology. This appraisal of the notion of the soul in Aristotle is to demonstrate that though the Aristotelian entelechy principle appears to be a philosophically convenient theory to argue that the soul of the dead must necessarily have a body after death if the entelechy principle must be sustained. However, it is 
philosophically inconsistent and problematic to use a principle in Aristotle's metaphysics of being to argue for the bodily resurrection of the soul, whereas a general philosophy of Aristotle does not support the immortality of the soul.

Based on the lurking contradictions in an effort to philosophically defend the resurrection of the body, the writer maintains that the discourse on the bodily resurrection is and should remain a theological problem. If it is agreed that Christian anthropology is Platonic, it would be rationally impossible to infer a bodily resurrection of the dead in a complete incorporeal realm of existence. Therefore, for the purpose of theological coherency, it is plausible to theologically sustain the bodily resurrection of the dead as B. P. Vysheslavtsev $(2002,178)$ maintains the belief that the resurrection of both the soul and the body of the dead "is essentially biblical and absolutely distinctive for Christianity. It runs completely counter to both the Platonic and Hindu theory of immortality, for both Greeks and Hindus regarded the resurrection of souls and bodies as absurd: not only impossible, but nothing one should even wish for."

\section{CONCLUSION}

Today the emphasis on Christian anthropology is that the human person is a unitary or integral of body and soul. Contrary to this position, the writer maintains that Christian anthropology, especially during the period of the early Christians, fundamentally conceives the human person as a composite of soul and body, which is a conscious employment of Platonic anthropology. The writer observes that, as regards the doctrine of the resurrection of the dead, there is a dichotomy between theological coherency and the actual Christian practice on the Christian conception of the human person. This work was executed by discussing: 1. A brief exposé on philosophical anthropology. 2. A brief navigation of biblical anthropology. 3. An exposition of Platonic anthropology. 4. Early Christian anthropology and Its Platonic Influence. 5. The implication on the Resurrection of the dead and on the Resurrected body.

\section{NOTES}

1. This should be distinguished from ruach, usually translated in English as "spirit."

2. See Genesis chapters 1,2 , and 3.

3. See Psalms 88:3, 5; 49:12; 20, Ecclesiastics 9:2-3. While Sheol is the place for all the dead, Hades is mainly for the wicked when they die.

4. Neil Gillman $(2015,56)$ summarizes the Jewish notion of death thus: "Death is punishment for sin; it is part of God's original creation of man; it is the inevitable result of humanity achieving self-awareness and the power of discrimination, or it is an independent power over which God does not yet exercise full control. The first three explanations are based on interpretations of the early Genesis texts, which, in varying ways, view death as a conscious divine decree. The last, which stems from an alternative creation tradition that is preserved in other biblical texts, views death as a force which, within history, remains independent of God's will." 
5. 2 Maccabees, chapter 7:9,11,14, 23, 29; 12:38-46; 14:46; Daniel 12:2; 2 Enoch chapter 49, 50, 51, 65.

6. For further reflection on Jewish Eschatology, see Neil Gillman (2015).

7. The quotations from Phaedo are according to Plato Complete Works, John M. Cooper and D.S. Hutchinson (eds.), (1997).

8. In other dialogues of Plato, he renders a slightly different notion of the soul. (See Republic 429-430; Timaeus 35-36 and Laws X 897a).

9. See Phaedo, 73 and Phaedo, 92c, respectively.

10. David J. Yount (2014) did a brilliant job in exposing the parallel that exists between Plato and Plotinus, in particular reference to metaphysics.

11. All quotes from the works of Plotinus, is according to Porphyry on Plotinus Ennead, A. H. Armstrong (translator) Cambridge: Harvard University Press, 1966.

12. That Plotinus was not only influenced by the Gnostics but that he substantially used the Gnostic's mythology on the soul to formulate his Platonic metaphysics of the soul has been demonstrated by Th. G. Sinnige (1999).

13. The notion of logos is not unique to Plotinus; it is a key concept in Stoicism.

14. A reference to Republic IX 590a9 and 588c7.

15. An exception could be Stoicism.

16. The Church has to affirm the goodness of the body as a creature of God against all heretic teachings and spirituality that demonize the human body, such as Gnosticism, Manicheanism, and Jansenism.

17. John R. Willis (1966, p. 491) makes an elaborate survey of this position of death by making a list of important figures and intellectual giants of the period of the Early Christians thus: "Death as a separation of the soul from the body is graphically described in St. Augustine's City of God, but the idea has already been set forth by St. Irenaeus in the second century, by Tertullian in the third, and by St. Gregory of Nyssa in the fourth. As early as St Clement of Rome, we read that after death, there is no possibility of meriting or demeriting; St Cyprian mentions this several times, and later St. Gregory Nazianzen and St. John Chrysostom”.

18. Margaret R. Miles argues that the Christian anthropology is basically the unity or integration of body and soul while affirming that the Early Christian in practice conceives the human person in the classical sense of the composite of body and soul, contends that: "It is important to remember that late classical people, pagan and Christian, had a great deal in common with each other; the experience of discomfort with being in a body appears in Christian thought because patristic writers are classical men, not because it is characteristically Christian" (Margaret R. Miles 1979, 4).

19. Karl Rahner $(1961,16)$ maintains that in the Old Testament, there is no explicit conception of death as the separation of the soul from the body and contends that "the traditional Catholic formula of preaching describes death as the separation of body and soul."

20. As quoted in (John R. Willis, 1966, 518), Justin Martyr expounds his argument based on the power of God. See The First Apology (Ch. 18).

21. Rahner (1961, 16-17) prefers to use the term "description" to state the Church's understanding of death as the separation of body and soul, rather than the 
term "conception." For him, it is a theological description rather than a dogmatic or doctrinal conception of death by Christians.

22. Rahner $(1981,77)$ contends "flesh" "means the whole person" as a unity of body and soul. Joseph Ratzinger also makes a theological exposé of the belief in "The Resurrection of the Flesh," in the first three centuries of the Church, where he makes a distinction between "the resurrection of the dead" and "the resurrection of the flesh," due to the influence of the Jewish root and a change in the notion of the flesh in Pauline Letters. By which he contends, "In this way, early Christian debate turned into a wrestling match between Pauline and Johannine terminology, an altercation over the concrete content of Christian realism." See, Joseph Ratzinger (1988, 172-181).

23. For a brief exposition on the Egyptians conception of the body and resurrection during the Graeco-Roman period, see Mark Smith (2009, 27-41).

\section{REFERENCES}

Aquinas Thomas. 2018. Summa Theologica-Complete and unabridged edition. Translated by Fathers of the English Dominican Province. California: Coyote Canyon Press.

Aquinas Thomas. 2005. Of God and His creature: An annotated translation of the Summa Contra Gentiles. Translated by Joseph Rickaby. The Catholic Primer: www.catholicprimer.org.

Aristotle. 1984. The complete works of Aristotle (Vol. 1\&2). Edited by Barnes Jonathan. Princeton: Princeton University Press.

St. Augustine. 1950. The city of God. Translated by Marcus Dods. New York: Random House Inc.

Gillman, Neil. 2015. The death of death: Resurrection and immortality in Jewish thought. Woodstock: Jewish Lights Publishing.

Lumpkin, Joseph B. 2010. The Books of Enoch: The Complete Volume. Blountsville. AL: Fifth Estate Publishers.

Miles, Margaret R. 1979. Augustine on the body. Missoula: Scholars Press.

Plato. 1997. Complete works. Edited by John M. Cooper and D.S. Hutchinson. Indiana: Hackett Publishing Company, Inc.

Porphyry. 1966. On Plotinus Ennead. Translated by A. H. Armstrong. Cambridge: Harvard University Press.

Rahner, Karl. 1961. On the theology of death. New York: Herder and Herder.

Rahner, Karl. 1933. The resurrection of the dead. Translated by H. J. Stenning. London: Hodder and Stoughton Ltd.

Rahner, Karl. 1981. Theological investigations: Jesus, Man and the Church, (Vol. 17.). Translated by Margaret Kohl. New York: The Crossroad Publishing Company. Ratzinger, Joseph. 1988. Eschatology: Death and eternal life. Washington, D.C: The Catholic University of America Press.

Schopp, Ludwig, (Editor). 1947. The Fathers of the Church. New York: Bishop Litho, Inc and Miller \& Watson, Inc. 
Scotus, Duns. 1987. Philosophical writings. Edited by Allan Wolter. Indiana: Hackett Publishing Company, Inc.

Setzer, Claudia. 2009. Resurrection of the body in early Judaism and Christianity. In Deuterocanonical and Cognate Literature: Yearbook 2009 The Human Body in Death and Resurrection. Edited by Tobias Nicklas, Friedrich V. Reiterer, and Josep Verheyden. 1-12. Berlin/New York: Walter de Gruyer. (1-2).

Sinnige Th. G. 1999. Six lectures on Plotinus and gnosticism. Dordrecht: Kluwer Academic Publishers.

Smith, Mark. 2009. Resurrection and the body in Graeco-Roman Egypt. In Deuterocanonical and Cognate Literature: Yearbook 2009 The Human Body in Death and Resurrection, Edited by Tobias Nicklas, Friedrich V. Reiterer and Josep Verheyden. Berlin/New York: Walter de Gruyer. (27-41).

Vysheslavtsev. B. P. 2002. The eternal in Russian philosophy. Translated by Penelope V. Burt. Michigan/Cambridge: William B. Eerdmans Publishing Company.

Willis, John R. (Editor). 1966. The teachings of the Church Fathers. New York: Herder and Herder, Inc.

John Paul II. 2006. Man and woman He created them: A theology of the body. Translated by Michael Waldstein. Boston: Pauline Books \& Media.

Yount, David J. 2014. Plotinus the Platonist: A comparative account of Plato and Plotinus' Metaphysics. London: Bloomsbury Publishing Plc. 